This is not to say that specialists should confine themselves entirely to their own subjects. Both parties must know the groundwork of the other subject for a collaboration to be successful. The specialization on insecticides research should resemble mountain peaks connected by ridges and passes, and not the isolated specialization of the branches of $a$ tree. That is probably true for other types of research also.

1 Tattersfleld, F., Ann. Appl. Biol., 26, 365 (1939)

${ }^{2}$ Cotton, R. T., J. Econ. Entom:, 25, 1088 (1932).

Tattersfield, F., and others, J. Agric. Sci., 10, 199 (1920) ; 17, 181 (1927). - Tattersfleld, F., and others, Ann. Appl. Biol., 12, 218 (1925) ; 13,
424 (1926).

${ }^{6}$ Ferguson, J., Proc. Roy. Soc., B, 127, 387 (1939).

- Busvine, J. R., Nature, 150, 208 (1942).

? Hazelhoff, E. H., Z. vergl. Physiol., 5, 179 (1927).

8 Wigglesworth, V. B., Bull. Ent. Res., 33, 205 (1942).

- Krüger, F., Z. d. angew. Entom., 18, 344 (1931), and others.

10 Hurst, H., NATURE, 145, 462 (1940).

i Clark, A. J., "The Mode of Action of Drugs on Cells" (London : Arnold and Co., 1935).

\section{PRODUCTION OF MAGNESIUM}

$\mathrm{M}$ AGNESIUM is to-day a metal of the greatest importance, and the paucity of reliable information regarding the production of this latest addition to the industrially important metals makes especially welcome the survey given by Dr. C. H. Desch in the Peter Le Neve Foster Lecture to the Royal Society of Arts delivered on February 17.

Magnesium, the lightest of all the industrial metals, is a new-comer to metallurgy. Although first prepared by Davy in 1808, it has only become really well known in the course of the present War, though its production had been increasing for some years before.

The pure carbonate is of only local occurrence, though there are very large deposits of a lower degree of purity. The double carbonate of calcium and magnesium, dolomite, is far more widely distributed, and sea water provides an inexhaustible source of the chloride in a dilute form, while certain concentrated solutions of magnesium salts occur in the Dead Sea and elsewhere.

The fact that magnesium alloys are available which are extremely light for a given strength renders the new metal one of great importance in all branches of transport engineering. The output of the United States is planned at a rate of some hundred times that of 1940 , but the industry is far from being merely a war-time one and will certainly play a permanent part in both metallurgy and engineering.

The preparation of magnesia from sea water is not new, going back to the early days of the basic Bessemer process, but it is only in very recent years that it has beccome of real importance. Oceanic water contains about $0 \cdot 14$ per cent of magnesium, and the process is represented by the simple reaction :

$$
\mathrm{MgCl}_{2}+\mathrm{Ca}(\mathrm{OH})_{2} \rightarrow \mathrm{Mg}(\mathrm{OH})_{2}+\mathrm{CaCl}_{2},
$$

the relatively insoluble magnesium hydroxide being precipitated. It is, however, often necessary to remove other salts by the addition of lime prior to the recovery of the magnesium, and conditions must be so adjusted that the particles are of such a size as to filter rapidly. By using calcined dolomite instead of lime, the yield is increased.
The earlier methods of reduction of the magnesia by an alkali metal have now only historical interest, but in 1830 Faraday decomposed molten magnesium chloride electrolytically; and in 1852, Bunsen improved this process and thus laid the foundation of that most widely used to-day. There are great advantages in employing a process which yields the anhydrous chloride in one operation; the alternative is to expel water from the hydrated salt, the last two molecules of water in which are retained somewhat firmly, the dehydration then often resulting in the formation of the oxide and oxychloride. This may be effected by taking advantage of the reaction between magnesia, dry chlorine and carbon.

$$
\begin{aligned}
\mathrm{MgO}+\mathrm{C}+\mathrm{Cl}_{2} & \rightarrow \mathrm{MgCl}_{2}+\mathrm{CO}, \\
2 \mathrm{MgO}+\mathrm{C}+2 \mathrm{Cl}_{2} & \rightarrow 2 \mathrm{MgCl}_{2}+\mathrm{CO}_{2} .
\end{aligned}
$$

As both these reactions are exothermic, the heat required is not great. The ground magnesia is mixed with carbon in the form of coke or anthracite dust, together with some material, such as sawdust or peat, to make the mass porous, and made into briquettes. Molten magnesium chloride in the anhydrous state is then tapped off from the base of the furnace.

Theoretically, the chlorine process is a cyclic one, the chlorine absorbed in the chlorination plant being again set free in the electrolytic cell. In practice, however, this recovery is by no means complete, a fact which is partly due to the formation of hydrochloric acid with moisture. It is necessary, therefore, both to add chlorine from some other source and to absorb the acid fumes in some sort of washing plant.

Full details of the electrolytic practice are not generally available, but in broad outline this consists of rectangular steel cells with graphite anodes and iron cathodes. The bath of fused salts usually contains chlorides of the alkali or alkali-earth metals in addition to the magnesium chloride, in order to lower the melting point as well as to lessen the decomposition, which is appreciable when the pure salt is kept in the molten state. Fluorides are also sometimes added. On account of the low density of magnesium, it floats on the surface, rendering it necessary to provide for the complete separation of the upper parts of the anode and cathode compartments, in order to prevent contact of the metal and the chlorine produced. The partitions are of ceramic material immersed from above. Large electrodes of good design are also necessary, each cell usually carrying 15-20,000 amp. with a potential difference of 7-9 volts. The bath temperature varies from $670^{\circ}$ to $750^{\circ} \mathrm{C}$., the energy consumption being about $20 \mathrm{kWh}$. per $\mathrm{kgm}$. of metal. The liquid magnesium is skimmed off from time to time, and with modern casting and remelting technique a very pure metal is obtained free from the inclusions of hygroscopic chlorides to which corrosion was once attributed.

Attempts to manufacture magnesium by processes similar to that used in the extraction of aluminium have so far proved a costly failure in the United States. The solubility of magnesia in molten fluorides is much less than that of alumina in cryolite, and the salt baths have both a higher melting point and density.

Magnesium being a volatile metal boiling at $1097^{\circ} \mathrm{C}$., the reduction of the oxide by a non-volatile reducing agent, carbon, calcium carbide, ferrosilicon, aluminium, etc., and the removal of the metal in the form of vapour has suggested itself to several inventors. The presence of even a small proportion 
of oxide, however, prevents the magnesium from forming a homogeneous mass ; hence it is necessary to work under conditions approximating to a vacuum. Although on the face of it a simple process, the reduction of magnesia by carbon presents many difficulties. The temperature needed is $2000^{\circ} \mathrm{C}$. or more, and the reaction is reversible. As the vapour cools, the oxide tends to reform, and even with an efficient condenser and dilution with an inert gas the dust obtained is contaminated with oxide. Using briquetted materials heated in an arc furnace, and cooling the vapour in a jet of strongly cooled hydrogen, by which means the temperature of the vapour is very quickly reduced to about $200^{\circ} \mathrm{C}$., the condensed dust may contain only 90 per cent of the metal. Redistillation is required in an atmosphere of hydrogen or natural gas with the filtration of the oxide particles, followed by direct condensation to the liquid state. It is not surprising that the process has proved difficult to carry out and that serious explosions have occurred.

The substitution of calcium carbide for carbon as the reducing agent eliminates the formation of a gaseous product which can bring about the reverse reaction on cooling. The reaction,

$$
\mathrm{MgO}+\mathrm{CaC}_{2} \rightarrow \mathrm{Mg}+\mathrm{CaO}+2 \mathrm{C},
$$

is carried out in vertical gas-fired retorts of heatresisting steel in which the mixture of magnesia and the carbide is heated. A vacuum is maintained, and the metal condenses in a compact form instead of as dust. Reduction with ferro-silicon occurs at a temperature of $1200-1400^{\circ} \mathrm{C}$. and possesses the advantage that calcined dolomite may be employed. This process is being developed on a large scale in the United States, where the ferro-silicon can be produced in electric furnaces in scattered plants having a surplus of hydro-electric power.

A process for the reduction of magnesia by alum. inium is an interesting example of the application of laboratory high-vacua technique on a commercial scale. The magnesia, obtained from sea water, is calcined, ground and mixed with aluminium or aluminium alloy. Briquetted under pressure, the mixture is charged into crucibles and pre-heated to about $400^{\circ} \mathrm{C}$. The crucibles have a downward central outlet leading to the condenser placed beneath. The self-contained unit consisting of crucible and condenser is raised into an electrically heated vertical cylindrical furnace. The furnace is then sealed and heated to $1100-1250^{\circ} \mathrm{C}$. under a pressure of less than $4 \mathrm{~mm}$. of mercury. The magnesium distils over into the water-cooled condenser, in which it solidifies as a mass of crystals of high purity ; the mass is readily transferred, on breaking the seal, to the remelting furnace, from which it is cast into ingots. A continuous furnace on the same lines has been designed, and, as aluminium swarf and other reducing agents may be employed, the process possesses great elasticity.

F. C. Thompson.

\section{NEWS and VIEWS}

\section{Research in the United States}

IN a recent statement made by Sir Ernest Simon before the Parliamentary and Scientific Committee, some outstanding facts were given concerning research in the United States. The research unit of the Bell Telephone Company, for example, has some 5,000-6,000 research workers concentrated on the one problem of telephonic communication. In the United States there seemed to be little need to persuade the business man, hard-headed though he be, of the value of research. $\mathrm{He}$ is now so firmly convinced by the results of the last twenty years, in peace and in war, of the necessity of research, that expenditure has risen to an astonishing figure, and, during the great depression, the research budget was the last to be cut. In 1940, according to an official report, industry was maintaining some 2,200 laboratories with a research staff of 70,000 , at an annual cost of three hundred million dollars. Sir Ernest wondered what the expenditure is in Great Britain; he doubted whether it was $£ 4,000,000$, yet it was to be noted that the United States population was only three times greater than ours. Per head he estimated that the United States were spending five times as much as we spend on university and industrial research. The results were significant. America now leads in hydrocarbon research, the world order being now : United States first, Germany second, Russia third and Great Britain fourth. Yet coal is our only special large-scale natural resource, and success in the difficult post-war period in exporting enough to pay for our essential imports will depend to a substantial extent on the most scientific treatment of our coal in order to get from it the maximum value.

This question of research is, of course, broadly divisible into two parts : research conducted by in dustrial organizations and research conducted by universities, and Sir Ernest Simon had some equally striking points to make concerning American universities. Their size and number is almost startling. When, during 1937-38, we had about 50,000 university students in Britain, America had a million. Their income was $£ 97,000,000$, while ours was just

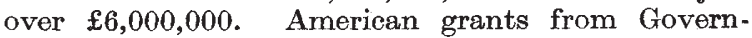
ment authorities were ten times, and from private generosity, twenty times as great as ours. In engineering, for example, there were, in the same year, 12,000 graduates from the American schools compared with about 800 in Great Britain. Now none more than ourselves realize that this comparison either of research or of numbers of universities and students may quite easily be very misleading. There are many factors which need close examination before final and valid conclusions can be drawn. The standards of graduate qualification must be closely examined and more particularly the work done by post-graduate students. The same care is needed when comparisons of arrangements for research are made, for research is a word capable of many interpretations. In saying that, we have no intention of attempting to detract from the vast and expert work of American research organizations and of American universities. By whatever test which may be applied it seems clear, from the points made by Sir Ernest Simon, that America has set and is setting an example which ought, without any avoidable loss of time, to be followed in Britain. The discussion which followed Sir Ernest's statement showed how the problem was appreciated by his listeners and gave indications of where research here should be encouraged and fostered. 